\title{
A sex related changes of the one humped camel (Camelusdromedarius) thyroid gland: (a histomorphological study)
}

\begin{abstract}
A histomorphological study of the thyroid glands of 15 healthy camels (Camelus dromedarius) of different sex group A (Males) and group B (Females), were investigated for gross and microscopic anatomy. Gross studies revealed that thyroid glands were located in between the third ring of trachea and the laryngopharynx portion of the pharynx and had two lobes, connected by an isthmus. They appeared to be reddish brown in colour. The values of weight, length, width and diameter of thyroid glands were show no significant difference between the groups $(\mathrm{P}>0.05)$. Histological observation revealed that the thyroid gland consisted of a connective tissue capsule and trabeculated were found extending from the capsule into the substance of the gland, which divided it into lobules. ${ }^{1}$ Each lobule consisted of two sized follicles in variable numbers, the large and small. The large follicles were lined by low cuboidal epithelium, while the small follicles were lined by high cuboidal to columnar epithelium. The follicles had colloid material in their lumen, probably an apocrine secretion from the lining epithelial cells. There was no evidence of Para follicular or C-cells in thyroid glands of camel.
\end{abstract}

Keywords: camel, thyroid gland, gross, histomorphology
Volume I Issue 3 - 2015

\author{
Bello A,' Onyeanusi BI,'2 Sonfada ML,' \\ Adeyanju JB, ${ }^{3}$ Umaru MA, ${ }^{4}$ Onu JE' \\ 'Department of Veterinary Anatomy, Usmanu Danfodiyo \\ University, Nigeria \\ 2Department of Veterinary Anatomy, Ahmadu Bello University \\ Zaria, Nigeria \\ ${ }^{3}$ Department of Veterinary Surgery and Radiology, Usmanu \\ Danfodiyo University, Nigeria \\ ${ }^{4}$ Department of Theriogenology and Animal production, Usmanu \\ Danfodiyo University, Nigeria
}

Correspondence: Bello A, Department of Veterinary Anatomy, Usmanu Danfodiyo University, Nigeria, Tel +234(0)8039687589, Email abccrcfge28@gmail.com

Received: October 08, 2015 | Published: October 30, 2015

\section{Introduction}

The thyroid is an endocrine gland which secretes thyroglobulin, triiodothyronine and thyroxin hormones. ${ }^{2,3}$ Thyroxin plays an important role in metabolism of the animal body. Thyroid gland consists of follicles lined by follicular cells. The intermolecular space has been reported to be filled with connective tissue. ${ }^{4,5}$ The most outstanding feature of the vertebrate thyroid gland is its ability to concentrate large amount of iodine for the synthesis of thyroxin. ${ }^{6}$ The normal anatomy and physiology of dromedarian camel is least understood when compared to Llama, Guanaco, Cattle, Sheep, Goat and Pig. ${ }^{5}$ The description of dromedarian camel is usually made as if it is identical with Llama specie. ${ }^{5,7}$ Though, they are seasonal breeders $^{5,8}$ that are closely related anatomically to the South American Camelids ${ }^{5,6,9,10}$ little is known on the anatomy and physiology of the thyroid gland. The present study was conducted to investigate the normal microscopic anatomy of thyroid gland of one humped camel (Camelus dromedarius) with the aim of understand the teaching of anatomy and physiology of the gland of the dromedarian Camel in the world.

\section{Materials and methods}

The study was carried out on 15 normal Adult one-humped camel collected from the metropolitan abattoir, Sokoto in winter season, using standard animal ethics approved by the government. The collected samples were then taken to the Veterinary Anatomy laboratory of Usmanu Danfodiyo University; where the gross and biometric values were determined. ${ }^{11} 1 \mathrm{~cm}^{2}$ thick of sample from each segment was collected and fixed in $10 \%$ formalin solution. After fixation was achieved, the tissue sample was processed for paraffin blocks preparation. The sections of $5 \mu \mathrm{m}$ were subjected to haematoxylin and eosin for routine morphology. The standard sections were examined under light microscope and micrographs taken using Sony digital camera $\left(\mathrm{x}^{5}\right)$ with 12.1 mega pixel.

\section{Results and discussion}

\section{Gross observations}

Gross studies of thyroid gland of camel revealed that the gland was located in between the third ring of trachea and the laryngopharynx portion of the pharynx and consisted of two lobes. An isthmus connected these lobes to each other and reddish brown in colour. This finding is similar to other large animals like cattle and buffaloes ${ }^{11}$ i.e., with the first ring of trachea and consisted of two lobes on both side and an isthmus connecting these lobes. In camel, the colour of the gland is in concordance with the findings of Schwartz and Dioli. ${ }^{12}$ The values of weight, length, width and diameter in camels of different sex groups viz male and female are presented in Table 1. The mean weight was 43.90 and $48.08 \mathrm{~g}$ in two groups respectively, which was slightly lower than previously reported value of $52.7 \mathrm{gm}$ in camel. ${ }^{13}$ It has been reported that in summer the size of the gland increases. ${ }^{14}$ The mean diameters recorded were 0.97 and $1.05 \mathrm{~cm}$ which fell in the range of 0.5 to $1.5 \mathrm{~cm}$ in adult camels. ${ }^{12}$ The mean length recorded was 5.36 and $6.36 \mathrm{~cm}$, and is in agreement to 3 to $8 \mathrm{~cm}$ reported by Abdel-Wahab and Hamza ${ }^{13}$ in camel. Similarly, the width of gland recorded was 3.35 and $3.53 \mathrm{~cm}$ and is in range of 1 to $4 \mathrm{~cm}$ reported earlier in this 
species. ${ }^{12}$ The statistical analysis revealed non-significant difference in various parameters between the two sex groups. However, the values of all the parameters were relatively higher in male camels compared with female group.

Table I Value (Mean \pm SD) of different parameters in camels of two age groups parameters

\begin{tabular}{lll}
\hline & Female & Male \\
\hline Weight $(\mathrm{g})$ & $45.70 \pm 0.35^{\mathrm{a}}$ & $50.55 \pm 0.26^{\mathrm{b}}$ \\
Length $(\mathrm{cm})$ & $5.36 \pm 0.46^{\mathrm{a}}$ & $6.36 \pm 0.33^{\mathrm{b}}$ \\
Width $(\mathrm{cm})$ & $3.35 \pm 0.29^{\mathrm{a}}$ & $3.53 \pm 0.21^{\mathrm{b}}$ \\
Diameter $(\mathrm{cm})$ & $0.97 \pm 0.13^{\mathrm{a}}$ & $1.05 \pm 0.14^{\mathrm{b}}$ \\
\hline
\end{tabular}

\section{Histological findings}

Histologically, the thyroid gland consisted of a connective tissue capsule composed of coarse and fine collagenous fibers with scattered fibroblast and small blood vessels all over the capsule (Figures 1-3).
The trabeculated were seen extending from the capsule into the substance of the gland and dividing it into lobules. Blood vessels were also present in the connective tissue of the trabeculated. Each lobule consisted of aggregation of follicles. Three types of follicles were identified, large (A), medium (B) and small (C) (Figure 4). The large follicles were lined by low cuboidal epithelium having flattened nuclei and were assumed to be inactive cells while the medium follicles were lined by columnar epithelium having oval nuclei. The small follicles were lined by cuboidal epithelium with rounded nuclei, these were active cells. Each follicle was filled with a gel-like material called colloid (Figure 3). The colloid is a storage form of follicular epithelial secretion. There is no evidence of Para follicular or C-cells in thyroid glands of camel. This result shown similar observations as reported previously in camel ${ }^{15,16}$ i.e. the gland consisted of follicles of variable sizes with smaller lined by low cuboidal to semi squamous epithelium, while the larger ones were lined by high cuboidal to columnar epithelial cells. The parafollicular or C-cells were found missing but has been reported in cattle and buffaloes. ${ }^{17}$ Similar observations have been recorded by Abdel-Magied et al. ${ }^{15}$

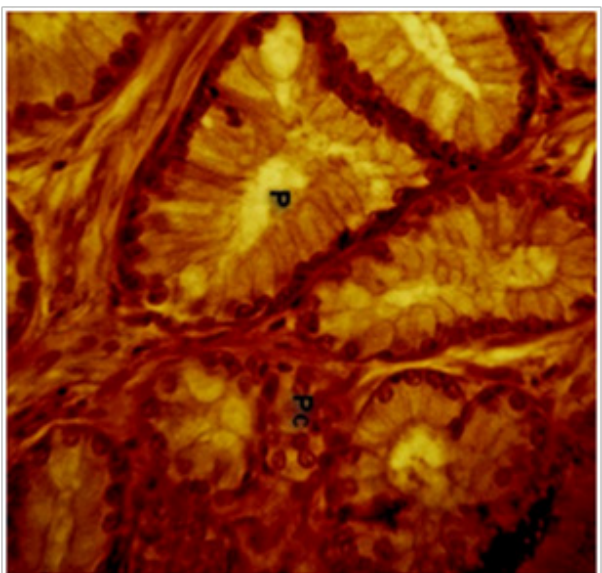

Figure I

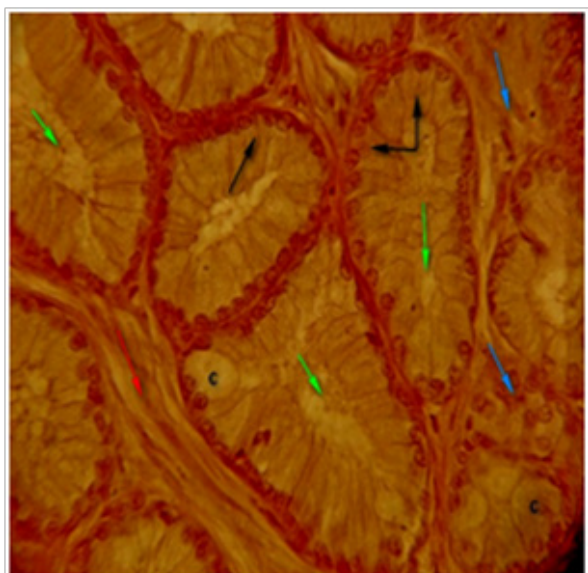

Figure 2

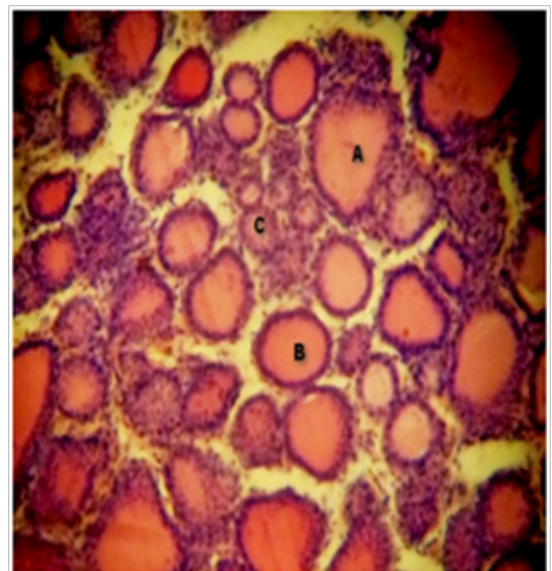

Figure 3

Figures I-3 Thyroid gland consisted of a connective tissue capsule composed of coarse and fine collagenous fibers with scattered fibroblast and small blood vessels all over the capsule.

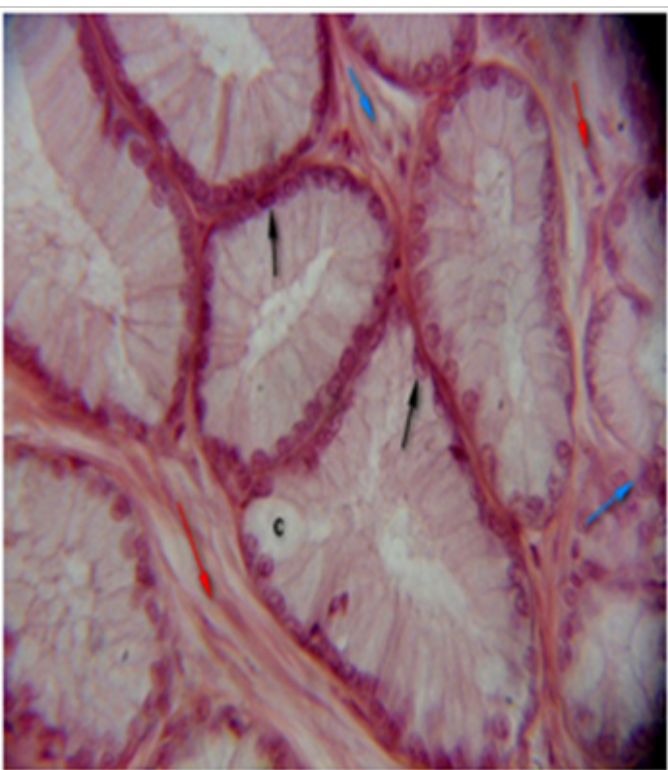

Figure 4 Aggregation of follicles.

\section{Conclusion}

Base on the above findings, it can be concluded that thyroid gland does not vary considerably in weight, length, width and diameter between male and female adult camels.

\section{Acknowledgements}

None.

\section{Conflict of interest}

Author declares that there is no conflict of interest.

\section{References}

1. Bancroft JD, Stevens A. Theory and Practice of Histological Techniques. 3rd ed. London: Churchill Livingston; 1990.

2. Banks WJ. Applied Veterinary Histology. 3rd ed. USA: Mosby-Year Book; 1993. p. 414-415.

3. Anonymous. SAS release 6.1.2. SAS Institute Inc., SAS Campus Drive. Cary, North Carolina, USA; 1996.

4. Asari M, Oshige $\mathrm{H}$, Wakui $\mathrm{S}$, et al. Histological development of bovine abomasus. Anat Anz. 1985;159(1-5):1-11. 
5. Bello A, Onyeanusi BI, Sonfada ML, et al. A biometric study of the digestive tract of one-humped camel (camelus dromedarius) fetuses. Scientific Journal of Zoology. 2012;1(1):11-16.

6. Georgieva R, Gerov K. The morphological and functional differentation of the alimentary canal of pig during ontogeny. I. Developmen and differentation of the fundic portion of the stomach. Anat Anz. 1975;137(1-2):12-15.

7. Bustinza AV. South American Camelids. In: IFS Symposium Camels, Sudan; 1979. p. 73-108.

8. Bello A, Sonfada ML, Umar AA, et al. Age estimation of camel in Nigeria using rostral dentition. Scientific Journal of Animal Science. 2013;2(1):9-14.

9. Belknap EB. Medical problems of llamas. In: The Vet. Cl. of N. Amer, Food Animal Practice, Update on Llama Medicine. In: Johnson LW, editors. Philadelphia; 1994.

10. Dellmann HD, Eurell JA. Textbook of Veterinary Histology. 5th ed. Baltimore: Lippincott Williams and Wilkins; 1998.

11. Getty R, Sission S, Grossman JD. The Anatomy of Domestic Animals. 5th ed. In: Leeson TS, Leeson CR, editors. Histology. 2nd ed. Philadelphia: WB Saunders Company; 1986.
12. Schwartz HJ, Dioli M. The one-humped camel in Eastern Africa. A pictorial guide to diseases, health care and management. Schonwald Druck. Berlin FR, Germany; 1992. p. 228-229.

13. Abdel-Wahab MF, AE Hamza. Thyroxin contents in thyroid glands of domestic animals. IV. Thyroid activity of camel, cattle, sheep and goats in Sudan. Endokrinologie. 1970;56(2):206-212.

14. Yagil RZ, Etzion Z, Ganani J. Camel thyroid metabolism: effect of season and dehydration. J Appl Physiol Respir Environ Exerc Physiol. 1978;45(4):540-544.

15. Abdel-Magied EM, Taha AA, Abdalla AB. Light and electron microscopic study of the thyroid gland of camel (Camelus dromedarius). Anat Histol Embryol. 2000;29(6):331-336.

16. Atoji Y, Yamamoto Y, Suzuki Y, et al. Ultrastructures of the thyroid gland of the one-humped camel (Camelus dromedarius). Anat Histol Embryol. 1999;28(1):23-26.

17. Miyandad P. Anatomical studies of the thyroid gland of buffalo. Faisalabad: MSc Thesis. Univ. Agri; 1973. 